ENTREPRENEURSHIP AND SUSTAINABILITY ISSUES

ISSN 2345-0282 (online) http://jssidoi.org/jesi/

2021 Volume 8 Number 4 (June)

http://doi.org/10.9770/jesi.2021.8.4(37)
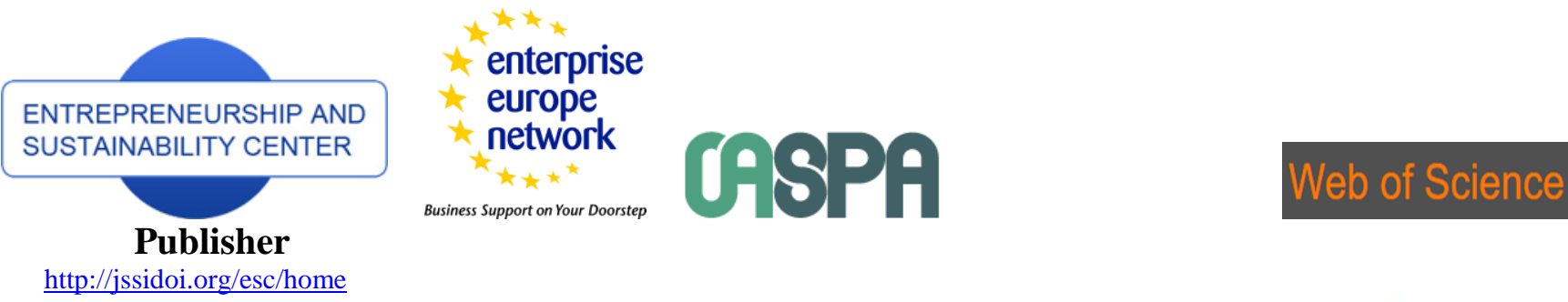

http://jssidoi.org/esc/home

Business Support on Your Doorstep

1 Clarivate

Analytics

\title{
SUSTAINABLE LEADERSHIP AND SUSTAINABLE PERFORMANCE OF HOSPITALITY FIRMS IN SOUTH AFRICA
}

\author{
Olawale Fatoki \\ Department of Business Management, University of Limpopo, Private Bag X1314, Sovenga, 0727, South Africa
}

Email: olawale.fatoki@ul.ac.za

Received 20 February 2021; accepted 3 May 2021; published 30 June 2021

\begin{abstract}
Sustainable leaders use the resources of their organisations to solve environmental and social challenges while generating value for the shareholders. This study investigated the relationship between sustainable leadership and sustainable performance of hospitality firms. Financial, social, and environmental indicators were used to measure sustainable performance. The study used the quantitative research method and the cross-sectional survey method was used to collect data from 192 respondents. Descriptive statistics, Pearson correlation, and regression analysis were used for data analysis. The results indicated significant positive relationships between sustainable leadership and financial, social, and environmental performance of hospitality firms. Recommendations to improve sustainable leadership in hospitality firms include a training and a reward system that focuses on sustainable leadership and performance. Limitations and areas for further study are discussed.
\end{abstract}

Keywords: Sustainable leadership; sustainable performance; hospitality; tourism; South Africa

Reference to this paper should be made as follows: Fatoki, O. 2021. Sustainable leadership and sustainable performance of hospitality firms in South Africa. Entrepreneurship and Sustainability Issues, 8(4), 610-621. http://doi.org/10.9770/jesi.2021.8.4(37)

JEL Classifications: M14

\section{Introduction}

Virakul and Russ-Eft (2019) point out that in the last three decades, many countries worldwide have been positively impacted by the effects of globalisation, capitalism, and consumerism. However, these factors have also created challenges such as climate change, depletion of natural resources, pollution, weak energy supplies, financial disruptions, and geopolitical conflicts. According to the Global Risk Perceptions 2021 report, the highest likelihood risks in the next ten years include extreme weather, human-led environmental damage, unemployment and livelihood crisis, youth disillusionment, and erosion of social cohesion (World Economic Forum, 2021). Jacobs and Mazzucato (2016) argue for the rethinking of capitalism because the current economic system has led to three fundamental and interconnected problems. These are stagnant economic growth in many countries, increasing inequality and declining standards of living and environmental challenges. The increasing levels of 


\section{ENTREPRENEURSHIP AND SUSTAINABILITY ISSUES}

ISSN 2345-0282 (online) http://jssidoi.org/jesi/

2021 Volume 8 Number 4 (June)

http://doi.org/10.9770/jesi.2021.8.4(37)

social and environmental issues have triggered international and local policies aimed at promoting inclusive and sustainable growth (Mensah, 2019). In 2015, the United Nations set out 17 goals aimed at achieving a better and more sustainable future. Based on the principle of "leaving no one behind", the goals emphasise a holistic approach to achieving sustainable development for all people and countries (United Nations, 2015). Africa's Agenda 2063 aims to create and sustain a high standard of living and quality of life for all Africans and create environmentally sustainable economies and communities (African Union, 2015). South Africa's National Development Plan 2030 aims to eliminate poverty and reduce inequality and create an environmentally sustainable economy (South African Government, 2013).

Businesses have a major role in promoting sustainable development and modern enterprises are moving from an approach that focuses on promoting short-term value for shareholders to a long-term sustainable value orientation that accepts that the economy, business, society and environment are interconnected. Many businesses have incorporated sustainability policies, principles, and practices into their operation and reporting (Stavropoulou, 2015; Burawat, 2018). Tideman et al. (2013) argue that sustainable business is the only business of business. One of the ways to achieve sustainable development is for business organisations to accept the challenges of sustainability as an opportunity and transform their business models accordingly. Sustainability is a new business trend that has fundamentally changed the demands placed on business leaders and has created a new type of leadership termed sustainable leadership (Virakul, 2015; Igbal et al., 2020).

A sustainable leadership (SL) strategy depends on an organisation that is flexible and adaptive to change with the goal of creating value for shareholders and society and is a holistic approach to business management (McCann and Holt, 2010; Zulkiffli and Latiffi 2016). SL considers the connection among business, society, and environment, and value is created on the basis of long-term strategic decision-making (Iqbal et al., 2020). Sustainable leaders use the resources of the organisation to solve environmental and social challenges while generating value for the shareholders. Profit is derived from shared value, which is the result of an intentional collaboration with stakeholders (Tideman et al., 2013; Suriyankietkaew and Avery, 2016, Armani et al., 2020). In addition, there is a shift in the way that the performance of business organisations is measured from the traditional financial measure to a sustainable measure that includes social and environmental indicators. The effective integration of financial, social, and environmental measures gives a more complete measure of business performance (Elkington, 1998; Hourneaux et al., 2018; Iqbal et al., 2020).

This study aims to investigate the relationship between sustainable leadership (SL) and sustainable performance (SP) of hospitality firms. The study will be significant in the following ways. First, empirical studies on the relationship between SL and firm performance are generally lacking (Suriyankietkaew and Avery, 2016; Burawat, 2019; Iqbal et al., 2020). Lee (2017) remarks that although researchers have done a good job in explaining the significance of SL, empirical support is not as robust as theoretical arguments. SL studies are still at the stage of infancy and there is a need to extend the literature in this field (Burawat, 2019). Second, most studies linking sustainable leadership with performance have been conducted on large firms and have tended to focus on financial performance (Suriyankietkaew and Avery, 2016). Third, sustainability is currently a very important topic in the tourism and hospitality industry, and guests are increasingly using sustainability practices to choose where they stay. Sustainable leadership is needed to introduce and manage sustainable practices in the hospitality industry for sustained competitive advantage and enhanced performance. The findings of this study will be useful to hospitality firms in understanding how sustainability leadership can affect not only financial, but also their social and environmental performance. The study is structured as follows. Section two will review the literature and develop hypotheses. Sections three, four, five, and six will focus on the research methodology, results, discussion, and conclusion, respectively. 


\section{ENTREPRENEURSHIP AND SUSTAINABILITY ISSUES}

ISSN 2345-0282 (online) http://jssidoi.org/jesi/

2021 Volume 8 Number 4 (June)

http://doi.org/10.9770/jesi.2021.8.4(37)

\section{Literature Review}

\subsection{Sustainable leadership (SL)}

Sustainable development has materialised as one of the challenging issues worldwide and different stakeholders such as customers and governments are putting pressure on business organisations to perform sustainably. Sustainability requires leaders who are able to combine financial with social and environmental performance (Iqbal et al., 2020). Just like leadership, there is no single universally acceptable definition of SL. Table 1 presents some of the Definition of SL.

Table 1. Definition of SL

\begin{tabular}{|c|c|}
\hline Author and year & Definition of SL \\
\hline Ferdig $(2007, \mathrm{p} 32)$ & $\begin{array}{l}\text { "Sustainable leaders take conscious actions, individually or collectively leading to } \\
\text { outcomes that nurture, support, and sustain economic, environmental and social systems" }\end{array}$ \\
\hline Russell Reynolds Associates $(2015, \mathrm{p} 3)$ & $\begin{array}{l}\text { "Sustainable leaders look beyond immediate, short-term gains to see the role their } \\
\text { organization plays in a larger context. They set strategies and ensure the delivery of results } \\
\text { that meet the triple bottom line of social, environmental, and financial performance" }\end{array}$ \\
\hline Sustainability Leadership Institute (2011) & $\begin{array}{l}\text { "'individuals who are compelled to make a difference by deepening their. awareness of } \\
\text { themselves in relation to the world around them }\end{array}$ \\
\hline Avery and Bergsteiner $(2011$, p. 6) & $\begin{array}{l}\text { "the objective of sustainable leadership is to keep people, profits, and the planet in balance } \\
\text { over the life of the firm }\end{array}$ \\
\hline Visser and Courtice $(2011$, p. 3) & $\begin{array}{l}\text { "“"A sustainability leader is someone who inspires and supports action towards a better } \\
\text { world." }\end{array}$ \\
\hline Pastore (2020, p. 27) & $\begin{array}{l}\text { "The Sustainable Leader is a person capable of identifying, inspiring and implementing } \\
\text { strategies, policies, Managerial behaviour consistent with the principles and purposes of } \\
\text { sustainability" }\end{array}$ \\
\hline
\end{tabular}

$$
\text { Source: various authors }
$$

Tideman et al. (2013) point out, three new mindsets and three new skill sets are needed to be a sustainable leader. This is termed the 6C of SL model. These include (1) context: which involves the recognition of interdependence, complexity and interconnectedness, (2) consciousness: this involves worldviews and a new mindset (3) continuity: this is a long-term horizon (4) connectedness: this involves serving the needs of all stakeholders (5) creativity: this includes using innovation to create sustainable share valued and (6) collectiveness: this includes collective impact and putting sustainability in the structure of the business. A sustainable leader is expected to have six competencies. These are influencing, collaborating, commercial awareness, delivering results, the anticipation of long term trends and the evaluation of long-term trends (Tideman et al., 2013). According to Slankis (2006), the ten pillars of SL include change orientation, broad system thinking, environmental and social consciousness, business savvy that links sustainability to stakeholder values, adaptability and change, patience, transnational skills, persuasiveness through communication and relationship building, energy and passion and mentoring and development.

SL is essential to a modern day business and there is a movement away from corporate greed to a sustainable business model (Francoeur et al., 2017). Business organisations need sustainable leaders because the world's complex transnational issues such as climate change, social disruption, and pressure on natural and food resources cannot be solved by political institutions alone. Sustainable leaders are needed to balance short-term and longterm priorities and to create value for a diverse group of stakeholders (Russell Reynolds Associates, 2015). SL 


\section{ENTREPRENEURSHIP AND SUSTAINABILITY ISSUES}

ISSN 2345-0282 (online) http://jssidoi.org/jesi/

2021 Volume 8 Number 4 (June)

http://doi.org/10.9770/jesi.2021.8.4(37)

can enable an organisation to achieve and sustain competitive advantage through innovation and operation of the business in an ethical manner (Slankis, 2006). The theoretical foundation of sustainable leadership can be linked to the Stakeholder theory, the Resource-based view of the firm and the Shared Value concept. The Stakeholder theory (Freeman, 1984), supports an interconnected relationship between a business and its investors, employees, customers, communities, and others that have a stake in the organisation. Therefore, value should be created by an organisation not only for shareholders but for all stakeholders. A sustainable leader is an individual who is able to create profit for his/her stakeholders, while improving the community and protecting the environment (Schwalb, 2011). The RBV (Barney, 1991) explains the link between resources, capabilities, and sustainable competitive advantage. The RBV focuses on how a firm uses resources and capabilities to reach a position of sustained competitive advantage and a higher level of performance. According to the RBV, a firm is a collection of distinctive resources and capabilities that must be optimally employed by management. The RBV argues that firms are heterogeneous in terms of capabilities, competencies, and resources, and their long-term success depends on how they efficiently and effectively utilise these capabilities in the dynamic marketplace. In addition, for a resource to contribute to sustainable competitive advantage, it must be rare, valuable, inimitable, and nonsubstitutable (Barney, 1991). Leadership is needed to effectively utilise organisational resources to achieve competitive advantage. The Shared Value concept puts emphasis on the identification of the connections between economic and societal progress. Shared values is a result of the use of the policies and practices of a firm to gain competitive advantage while improving the community in which the firm operates (Porter and Kramer, 2011). Leadership has a significant role in shared value creation and a business leader is expected to use resources to benefit the firm and the community (Chen et al., 2018).

\subsection{Sustainable performance}

Bouloiz (2020) points out that business organisations are currently evolving in the context of the use of natural resources and the way that they maintain relationships with employees and the community. Therefore, businesses are not just focusing on financial performance but also on social and environmental performance. While financial performance focuses on indicators such as profitability, market share, and sales, social performance focuses on stakeholders such as employees, customers, and civil society. Environmental performance focuses on environmental efficiency and the set of measurable indicators of the Environmental Management System. Slaper and Hall (2011) point out that a sustainable business creates profit for its shareholders while also improving the lives of those that it has an interaction with and protecting the environment. The Triple Bottom Line (TBL) states that for a business to be sustainable, it must be financially strong, minimise or eliminate its negative environmental impacts, and act in accordance with social expectations. (Elkington, 1998). The sustainable performance approach unites the concept of sustainability with performance and is a framework for measuring and reporting organisational results on the basis of economic, social, and environmental parameters (Hourneaux et al., 2018).

\subsection{Sustainable leadership and sustainable performance}

Kiron et al. (2013) and Virakul and Russ-Eft (2019) remark that some of the benefits of sustainability in business organisations include competitive advantage, enhancing corporate governance and corporate social responsibility, and better financial performance. According to Choi and Yu (2014), business sustainability practices positively affect performance through the strengthening of employees' commitment and organisational citizenship behaviour. Sustainability practices in business organisations align employees with ethical behaviour and lead to the creation of a principled ethical climate (Siletti et al., 2015). High sustainability business organisations tend to have better established processes for stakeholder engagement, longer-term orientation, tend to use both financial and nonfinancial measures, and in the long-term significantly outperform low sustainability firms in terms of accounting and stock market performance (Eccles et al., 2014). 


\section{ENTREPRENEURSHIP AND SUSTAINABILITY ISSUES}

ISSN 2345-0282 (online) http://jssidoi.org/jesi/

2021 Volume 8 Number 4 (June)

http://doi.org/10.9770/jesi.2021.8.4(37)

Suriyankietkaew and Avery (2016) examine the effect of SL on the financial performance of small and medium enterprises in Thailand. The SL questionnaire by Avery and Bergsteiner (2010) was used to measure SL, while financial performance was subjectively measured by the perception of growth in sales, net profits, and cost control in the past three years. The findings based on a data set of 439 first-line and middle level managers revealed that 16 out of 23 SL practices are significantly related to firm performance.

Lee (2017) investigated the effect of five elements of SL (cohesive diversity, organisational justice, employee development, process orientation, and work/life balance) on organisational effectiveness.at micro and macro levels. The study used a large nationwide data that was collected from employees of different agencies of the United States of America federal government. The findings indicate that different elements of SL affect different aspects of organisational effectiveness to a different degree. Burawat (2019) examines the relationship between SL and SP of small and medium enterprises in the manufacturing sector in Thailand. Data was collected from 598 respondents in 374 firms. The Avery and Bergsteiner (2011) SL practices were unidimensionally used to measure SL. Financial, social, and environmental measures were used to measure sustainable performance. The results indicate a significant positive relationship between SL and SP.

Iqbal et al. (2020) examine the indirect effect of SL on SP through organisational learning. The study used a dataset collected from employees working in managerial positions of 369 SMEs in Malaysia, Indonesia, and Brunei Darussalam. The study used the 15-item scale from the study of McCann and Holt (2010) to measure SL and focuses on the perception of employees. The findings confirm the mediating effect of organisational learning in the relationship between SL and SP. Iqbal et al. (2020) in a similar study used datasets from 405 small and medium enterprises in Kuala Lumpur (Malaysia), Jakarta (Indonesia), and Bandar Seri Begawan (Brunei Darussalam). The findings indicate that SL has a positive and indirect effect on SP through psychological safety.

Al-Zawahreh et al. (2018) point out that SL creates value for all stakeholders and leads to continuous improvement and innovation and is a successful strategy for long-term success and sustained competitive advantage. In addition, organisations that adopt SL practices reap benefits in the areas of efficiency in the consumption of energy and resources, better organisational image, reduced employee turnover, better community engagement, higher productivity, and lower costs. Consequently, it is hypothesised that:

Hypothesis one: There is a significant positive relationship between SL and financial performance.

Hypothesis two: There is a significant positive relationship between SL and social performance.

Hypothesis three: There is a significant positive relationship between SL and environmental performance.

\section{Research Methodology}

The study utilised the quantitative research design. Data was collected from the respondents through the crosssectional survey method. The survey was conducted between July 2018 and February 2019. The sample population was all hotels, lodges, and guest houses in South Africa. Before the actual survey, a pilot study was conducted with the owners/managers of thirty hotels, guesthouses, and lodges. Two academics in the area of Strategic Management also examined the questionnaire. Based on the results of the pilot study, minor adjustments were made in developing the final version of the questionnaire. The questionnaire was divided into three sections, demographic variables, SL, and SP (financial, social, and environmental). The survey was conducted in the Gauteng Province of South Africa and focused on accommodation establishments in Pretoria and Johannesburg. The Gauteng Province is the economic hub of South Africa and many hotels, guest houses, and lodges are located in the province. The participants in the survey were conveniently sampled. from some 


\section{ENTREPRENEURSHIP AND SUSTAINABILITY ISSUES}

ISSN 2345-0282 (online) http://jssidoi.org/jesi/

2021 Volume 8 Number 4 (June)

http://doi.org/10.9770/jesi.2021.8.4(37)

accommodation databases such as Centurion Bed and Breakfast Association, Tshwane Accommodation listing, Johannesburg Accommodation listing, Guesthouse Association of Tshwane and the Tourism Grading Association of South Africa. The study focused on formal service accommodation (hotels and lodges) and guest accommodation (Bed and Breakfast, Country house, and Guest house) (Tourism Grading Association of South Africa, 2018). The identified respondents in the study were managers or owners because they are more likely to have the necessary information about the SL and SP of their organisations. Managers/owners of accommodation establishments were formally contacted through telephone calls and e-mails to solicit their participation. A combination of email and self-administered questionnaire methods was used to collect data from the respondents. Confidentiality and anonymity were assured and the names of the hotels and or owner/manager were not requested nor included in the questionnaire. The participants in the survey were reminded weekly to complete the questionnaire through follow-up phone calls and emails. If no response is received after two months, it was treated as a nonresponse. The questionnaire was adapted from previous studies with acceptable psychometric properties. The cover page of the questionnaire contained information about the aim of the study and that participation is voluntary. The study used descriptive statistics, Pearson correlation, and linear regression for data analysis.

\section{Measures:}

SL was measured using the 23 item SL questionnaire developed by Avery and Bergsteiner (2010). Studies on SL by Suriyankietkaew and Avery (2016) and Burawat (2019 also used the questionnaire. The five-point Likert scale ranging from $1=$ "Strongly disagree" to $5=$ "Strongly agree" was used as the response category. The Cronbach's alpha for sustainable leadership is 0.78 .

Sustainable performance: Three indicators (financial, social, and environmental) were used to measure sustainable performance (Hourneaux et al., 2018; Iqbal et al., 2020). The study utilised perceptive measures for the last three years to measure sustainable performance (Suriyankietkaew and Avery, 2016);

Financial performance (FP): Three items (increase in sales, increase in market share, and increase in profit during the last three years) and anchored on five-point Likert scale with " 1 strongly disagree and 5 strongly agree" were used to measure to measure FP The items were adapted from previous studies (Suriyankietkaew and Avery, 2016; Hourneaux et al., 2018). The Cronbach's alpha for FP is 0.84 .

Social performance (SP): Five items adapted from previous studies (Rashid et al., 2015; Hernandez-Perlines and Cisneros, 2017) and anchored on using five-point Likert scale with "1 strongly disagree and 5 strongly agree" were used to measure SP. The items focus on both internal and external factors and include the following items, reduced staff turnover, increased customer satisfaction with products and services, increased employee satisfaction, increased contribution to the local community for social issues, and increased employee health and safety. The Cronbach's alpha for SP is 0.79 .

Environmental performance (EP): Five items adapted from previous studies (Qorri et al., 2018; Magsi et al., 2018) and anchored on the five-point Likert scale with "1 strongly disagree and 5 strongly agree" were used to measure EP. These were improvement in the efficiency of raw materials, reduction in resource consumption (energy and water), increase in recycling of materials, reduction in the cost of environmental compliance, and increased overall reputation in respects of products and services. The Cronbach's alpha for EP is 0.81 . 


\section{Results}

\subsection{Response rate and biographical information}

500 questionnaires were distributed to managers or owners of hospitality firms during the process of data collection. 192 questionnaires were returned and found usable. The biographical details of the respondents are as follows: education qualifications of the respondent: Matric no respondent, Matric, 45 respondents, and postmatric qualification 147 respondents. Gender of the respondent. Male 120, female 72. Age of respondents. Less than 20, no respondent,20-30 years, 7 respondents, 31-40 years, 59 respondents, 41-50 years, 73 respondents, and above 50. 53 respondents. Age of the firm, less than one year, no respondents, 1-5 years, 36 respondents, 6-10 years, 104 respondents, above ten years 52 respondents. Number of employees. No employee, no respondent, 1-5, no respondent, 6-20 employees, 33 respondents, 21-50 employees, 89 respondents, 51-200 employees, 70. The findings indicate that the majority of participating firms can be classified as small and medium enterprises (Government Gazette, 2003).

\subsection{Descriptive statistics and Pearson correlation}

Table 2. Descriptive statistics and Pearson correlation

\begin{tabular}{|l|l|l|l|l|l|l|}
\hline Construct & Mean & SD & 1 & 2 & 3 & 4 \\
\hline SL & 3.15 & 0.88 & 1 & & & \\
\hline FP & 3.42 & 0.94 & $0.708^{*}$ & 1 & & \\
\hline SP & 3.19 & 0.99 & $0.702^{*}$ & $0.692^{* *}$ & 1 & \\
\hline EP & 3.36 & 1.00 & 0.706 & $0.671^{*}$ & $0.666^{* *}$ & 1 \\
\hline
\end{tabular}

The results of the descriptive statistics and Pearson correlation are depicted in Table 2. SL has a mean score 3.15 with a standard deviation of 0.88 . FP has a mean score of 3.42 with a standard deviation of 0.94 . SP has a mean score of 3.19 and a standard deviation of 0.99. EP has a mean score of 3.36 and a standard deviation of 1.00. The correlation results show that SL is significantly associated with FP $(r=0.708 ; p<.001), S P(r=0.692, p<.005)$ and $\mathrm{EP}(\mathrm{r}=0.666, \mathrm{p}<.005)$

\subsection{Regression results}

Table 3. Regression results of SL and FP

\begin{tabular}{|l|l|l|l|l|l|}
\hline \multirow{2}{*}{ Model } & \multicolumn{2}{|l|}{ Unstandardized Coefficients } & $\begin{array}{l}\text { Standardized } \\
\text { Coefficients }\end{array}$ & S & \\
\cline { 2 - 4 } & B & Std.Error & Beta & \\
\hline Constant & 107.306 & 2.061 & & 2.204 & .000 \\
\hline EP & 1.046 & 0.482 & 0.692 & 12.008 & .000 \\
\hline $\mathrm{N}=192, \mathrm{R}=0.639, \mathrm{R}$ square 0.659, Adjusted R square 0.683, Sig.< 0.05 & \multicolumn{4}{|l|}{} \\
\hline
\end{tabular}

Source: author's data analysis

Table 4. Regression results of SL and SP

\begin{tabular}{|l|l|l|l|l|l|}
\hline \multirow{2}{*}{ Model } & \multicolumn{2}{|l|}{ Unstandardized Coefficients } & $\begin{array}{l}\text { Standardized } \\
\text { Coefficients }\end{array}$ & S & \\
\cline { 2 - 5 } & $\mathrm{B}$ & Std.Error & Beta & \\
\hline Constant & 103.022 & 3.106 & & 1.411 & .001 \\
\hline SP & 1.058 & 0.509 & 0.626 & 11.224 & .001 \\
\hline $\mathrm{N}=192, \mathrm{R}=0.609, \mathrm{R}$ square 0.620, Adjusted R square $=0.648$, Sig. $<0.05$ & \\
\hline
\end{tabular}

Source: author's data analysis 
ENTREPRENEURSHIP AND SUSTAINABILITY ISSUES

ISSN 2345-0282 (online) http://jssidoi.org/jesi/

2021 Volume 8 Number 4 (June)

http://doi.org/10.9770/jesi.2021.8.4(37)

Table 5. Regression results of SL and EP

\begin{tabular}{|l|l|l|l|l|l|}
\hline \multirow{2}{*}{ Model } & \multicolumn{2}{|l|}{ Unstandardized Coefficients } & $\begin{array}{l}\text { Standardized } \\
\text { Coefficients }\end{array}$ & T \\
\cline { 2 - 4 } & $\mathrm{B}$ & Std.Error & Beta & \\
\hline Constant & 105.112 & $2 . .994$ & & 2.094 & .001 \\
\hline $\mathrm{EP}$ & 1.026 & 0.613 & 0.602 & 12.122 & .001 \\
\hline $\mathrm{N}=192, \mathrm{R}=0.624, \mathrm{R}$ square 0.661, Adjusted R square 0.683, Sig. $<0.05$ & \\
\hline
\end{tabular}

Source: author's data analysis

The normal probability-probability plot was examined to measure the normality of the data. The normality of the data can be assumed because the data formed a straight line along the diagonal. In addition, a scatterplot of standardised residuals verses and standardised predicted values were created to assess homoscedasticity. The plot shows random scatter. To assess multicollinearity, variance inflation factors (VIFs). The VIF values were lower than six and this suggests that multicollinearity can be assumed. The regression results as depicted in tables 3,4 , and 5 indicate that there is a significant positive relationship between SL and FP $(\beta 0.692, \mathrm{p}<0.01)$, and SL and SP $(\beta 0.626, \mathrm{p}<.01)$ and SL and EP $((\beta 0.602, \mathrm{p}<.01)$. Thus, hypotheses 1,2 , and 3 that there are significant positive relationships between SL and FP, SP, and EP are accepted. It can be concluded that SL positively impacts on the sustainable performance of hospitality firms.

\section{Discussion}

Businesses have a major role in promoting sustainable development and modern enterprises are moving from an approach that focuses on promoting short-term value for shareholders to a long-term sustainable value orientation that accepts that the economy, business, society and environment are interconnected. SL considers the interconnection among business, society, and environment, and value is created on the basis of long-term strategic decision-making. The study investigated the effect of SL on SP of hospitality firms. Financial, social, and environmental indicators were used to measure sustainable performance. The results indicated that SL has a significant positive relationship with FP. Hypothesis one of the study is supported. The results are consistent with the findings of Suriyankietkaew and Avery (2016) that SL is a strong predictor and driver of firm FP. The findings of the study also support a significant positive relationship between SL and SP. Hypothesis two of the study is supported. Armani et al. (2020) point out that the attributes of SL include interpersonal skills, change, orientation, alignment with organisational culture, and attention to all stakeholder. A sustainable leader should be able to continuously develop employees, maintain good labour relations, train staff, undertake succession planning, and be socially responsible by maintaining a good relationship with the community. The findings also provide empirical support for a positive relationship between SL and EP. Hypothesis three of the study is supported. According to Avery and Bergsteiner (2010), a sustainable leader must efficiently use resources such energy and water, reduce pollution, and be environmentally responsible. Al-Zawahreh et al. (2018) point out that a sustainable leader creates value for all stakeholders and undertakes a strategy for long-term sustainable performance. The results are consistent with the findings of Burawat (2019) that there is a significant positive relationship between sustainable leadership and sustainable performance. Iqbal et al. (2020) find the mediating effect of organisational learning in the relationship between SL and SP. Another study by Iqbal et al. (2020) found that that SL has a positive and indirect effect on SP through psychological safety. 


\section{ENTREPRENEURSHIP AND SUSTAINABILITY ISSUES}

ISSN 2345-0282 (online) http://jssidoi.org/jesi/

2021 Volume 8 Number 4 (June)

http://doi.org/10.9770/jesi.2021.8.4(37)

\section{Conclusion}

This study investigated the relationship between SP and SP performance of hospitality firms. Financial, social, and environmental indicators were used to measure sustainable performance. The results indicated significant positive relationship between SL and SP. Theoretically, the study linked SL to firm financial and nonfinancial indicators. The study linked SL to sustainable performance (financial, social, and environment measures) and not just financial performance. This gives a holistic picture of how SL can impact on firm performance. Thus, the findings of the study show that a sustainable leader will not only improve firm financial performance but also social and environmental performance. A sustainable leader will be able to create value not only for shareholders but also for other stakeholders. Empirically, the study adds to the sparse studies on SL and firm performance, especially in the context of hospitality firms in a developing country. The study makes some recommendations to improve SL by hospitality firms. This includes the training of owners, managers, employees, and suppliers on SL. In addition, hospitality firms should use both financial and nonfinancial indicators to measure performance. Sustainability practices and reporting should be included in the operation and performance of hospitality firms. Leaders should develop sustainability policies and guidelines for their firms. The reward system in hospitality firms should focus on sustainable leadership and performance. The study has some limitations. First, it focused on a subjective rather than objective measures of sustainable performance. The participants in the survey are mainly small and medium-sized enterprises, and obtaining their objective results are often difficult. Second, the participants in the survey were conveniently sampled and this can lead to sampling bias. Third, only 192 owners/managers participated in the survey and care should be exercised in generalising the findings of the study. Fourth, the cross-sectional approach was adopted for the survey and this limits the ability to determine cause and effect. Other studies can use a longitudinal approach. The study focused on the owner/managers of hospitality firms. The perception of employees of hospitality firms about sustainable leadership can be determined using the 15 item sustainable leadership questionnaire by McCann and Holt (2011). The moderating effect of demographic variables (gender, age, and level of education of the owner/manager can also be investigated.

\section{References}

African Union, (2015) Agenda 2063: The Africa We Want. Retrieved October 16, 2018, from https://au.int/en/agenda2063/overview

Al-Zawahreh, A., Khasawneh, S. \& Al-Jaradat, M (2018). Green management practices in higher education: the status of sustainable leadership. Tertiary Education and Management. 25(4) https://doi.org/10.1007/s11233-018-09014-9

Barney, J. (1991). Firm resources and sustained competitive advantage. Journal of Management, 17(1), 99-120. http://dx.doi.org/10.1177/014920639101700108

Burawat, P. (2019). The relationships among transformational leadership, sustainable leadership, lean manufacturing and sustainability performance in Thai SMEs manufacturing industry. International Journal of Quality \& Reliability Management, 36(6), 1014-1036. https://doi.org/10.1108/IJQRM-09-2017-0178

Armani, A.B., Petrini, M. \& Santos, A.C. (2020). What are the Attributes of Sustainable Leadership? Revista Brasileira De Gestão De Negócios, 22(4), 820-835. https://doi.org/10.7819/rbgn.v22i4.4086

Avery, G.C. \& Bergsteiner, H. (2011). Sustainable leadership practices for enhancing business resilience and performance. Strategy \& Leadership, 39(3), 5-15. https://doi.org/10.1108/10878571111128766

Bendell, J \& Little, R. (2015. Seeking Sustainability Leadership. The Journal of Corporate Citizenship, Pretoria Leadership Conference (December 2015), 13-26

Bouloiz, H. (2020). Sustainable performance management using resilience engineering. International Journal of Engineering Business Management, 12, 1-12. https://doi.org/10.1177/1847979020976205 


\section{ENTREPRENEURSHIP AND SUSTAINABILITY ISSUES}

ISSN 2345-0282 (online) http://jssidoi.org/jesi/

2021 Volume 8 Number 4 (June)

http://doi.org/10.9770/jesi.2021.8.4(37)

Chen, R. Hung-Baesecke, C., Bowen, S. \& Zerfass, A. (2018). The role of leadership in shared value creation from the public's perspective: A multi-continental study. Public Relations Review, 46(1), 1-11.http://doi.org/10.1016/j.pubrev.2018.12.006

Choi, Y \& Yu, Y (2014). The Influence of Perceived Corporate Sustainability Practices on Employees and Organizational Performance. Sustainability, 6(1), 348-364. https://doi.org/10.3390/su6010348

Eccles, R., Ioannou, I. \& Serafeim, G. (2015). The Impact of Corporate Sustainability on Organizational Processes and Performance. Management Science, 60(11), 2835-2857. https://doi.org/10.1287/mnsc.2014.1984

Ferdig, M. (2007). Sustainability Leadership: Co-creating a Sustainable Future. Journal of Change Management, 7(1), 25-35. https://doi.org/10.1080/14697010701233809

Freeman, RE. (1994). The Politics of Stakeholder Theory: Some Future Directions. Business Ethics Quarterly, 4(4), 409-421. https://doi.org/https://doi.org/10.2307/3857340

Hernandez-P.F. \& Cisneros, M. (2017). Analysis of the moderating effect of entrepreneurial orientation on the influence of social responsibility on the performance of Mexican family companies. Cogent Business \& Management, 4(1) 1408209. https://doi.org/10.1080/23311975.2017.1408209

Hourneaux, F., Gabriel, M.N., \& Gallardo-Vázquez, D.A. (2018). Triple bottom line and sustainable performance measurement in industrial companies, Revista de Gestão, 25(4), 413-429. https://doi.org/10.1108/REGE-04-2018-0065

Jacobs, M \& Mazzucato, M. (2016) (eds) Rethinking Capitalism: Economics and Policy for Sustainable and Inclusive Growth, Wiley Blackwell: Chichester, 225 pp. 9781119120957

Igbal, Q., Ahmad, NH, \& Halim, H.A. (2020). How Does Sustainable Leadership Influence Sustainable Performance? Empirical Evidence From Selected ASEAN Countries. Sage Open, 1-16. https://doi.org/10.1177/2158244020969394

Iqbal, Q., Ahmad, NH, Nasim, A and Khan, SA (2020). A moderated-mediation analysis of psychological empowerment: Sustainable leadership and sustainable performance. Journal of Cleaner Production, 262(6) https://doi.org/10.1016/j.jclepro.2020.121429

Magsi, H., Ong, T., Ho, J. \& Hassan, A. (2018). Organizational Culture and Environmental Performance. Sustainability, 10(8), 2690-2707. https://doi.org/10.3390/su10082690

Kiron, D, Kruschwitz, N, Reeves, M \& Goh, E. (2013). The Benefits of Sustainability-Driven Innovation. MIIT Sloan Management Review, 54(2), 69-73. https://doi.org/10.1002/9781119204084.ch15

Lee, H.W. (2017). Sustainable leadership: an empirical investigation of its effect on organizational effectiveness. International Journal of Organization Theory and Behaviour, 20 (4), 419-453. https://doi.org/10.1108/IJOTB-20-04-2017-B001

McCann, J Holt, RA ^(2010). Defining sustainable leadership. International Journal of Sustainable Strategic Management, 2(2), 204-210. https://doi.org/10.1504/IJSSM.2010.032561

Mensah, J. (2019). Sustainable development: Meaning, history, principles, pillars, and implications for human action: Literature review. Cogent Social Sciences, 5(1), 1-21. https://doi.org/10.1080/23311886.2019.1653531

Pastore, A. (2020. Sustainable Leadership in Europe. https://sustainableleaders.eu/wp-content/uploads/2020/07/Sustainable-Leadership-inEurope-Report.pdf

Porter, M. E. \& Kramer, M. (2011). Creating shared value: How to reinvent capitalism and unleash a wave of innovation and growth. Harvard Business Review (January/February), 62-77.

Qorri A., Mujkić Z., \& Kraslawski A., (2018) A conceptual framework for measuring sustainability performance of supply chains. Journal of Cleaner Production, 1-32. https://doi.org/10.1016/i.jclepro.2018.04.073

Rashid, N., Khalid, S., \& Rahman, N. (2015). Environmental Corporate Social Responsibility: Exploring its influence on customer loyalty. Procedia Economics and Finance, 31, 705-713. https://doi.org/10.1016/S2212-5671(15)01159-4

Russell Reynolds Associates (2015). Sustainable leadership: talent requirements for sustainable enterprises. Retrieved October 16, 2018, https://www.russellreynolds.com/en/Insights/thought-leadership/Documents/russell_reynolds_sustainable_leadership.pdf

Schwalb, P. G. (2011). Sustainability leader competencies: A grounded theory study. (Doctoral dissertation). University of NebraskaLincoln, Lincoln, NE 


\section{ENTREPRENEURSHIP AND SUSTAINABILITY ISSUES}

ISSN 2345-0282 (online) http://jssidoi.org/jesi/

2021 Volume 8 Number 4 (June)

http://doi.org/10.9770/jesi.2021.8.4(37)

Slankis, E. (2006). Sustainable thinking, sustainable leadership-the new E.Q., Leadership, available at Retrieved October 16, 2018, http://www.rayberndtson.ca/fileadmin/assets/canada/Documents/PDFs/Sustain Thinking.pdf

Slaper, TF \& Hall, TJ. (2011). The Triple Bottom Line: What Is It and How Does It Work? Indiana Business Review, 4-8.

Siletti, E., Guerci, M, Cirella, S \& Shani, A. (2015). The Impact of Human Resource Management Practices and Corporate Sustainability on Organizational Ethical Climates: An Employee Perspective Journal of Business Ethics, 126(2), 325-342. https://doi.org/10.1007/s10551-013-1946-1

South African Government, (2013). National Development Plan 2030. Retrieved October 16, 2018 https://www.gov.za/issues/nationaldevelopment-plan-2030\#

Sustainability leadership Institute (2015). Sustainable leadership. $\quad$ Retrieved $\quad$ October $19, \quad 2018$. http://www.sustainabilityleadershipinstitute.org/leadership.php

Stavropoulou, AM. (2015). Innovation, sustainable leadership and consideration of future consequences: A cross-cultural perspective. Masters dissertation. Linnaeus University. https://www.diva-portal.org/smash/get/diva2:839622/FULLTEXT01.pdf

Suriyankietkaew, S \& Avery, GC (2016), Sustainable Leadership Practices Driving Financial Performance: Empirical Evidence from Thai SMEs. Sustainability, 8(4), 327. https://doi.org/10.3390/su8040327

Tideman, SG, Arts, M, \& Zandee, D (2013). Sustainable Leadership: Towards a Workable Definition. Journal of Corporate Citizenship, (49), 17-33. https://doi.org/10.9774/GLEAF.4700.2013.ma.00004

Virakul, B. (2015). Global challenges, sustainable development, and their implications for organizational performance. European Business Review, 27(4), 430-446. https://doi.org/10.1108/EBR-02-2014-0018

Virakul, B. \& Russ-Eft, D. (2019). A model for business responses to global challenges and sustainable development. Social Responsibility Journal, 16(2), 199-224. https://doi.org/10.1108/SRJ-09-2018-0223

Visser, W. \& Courtice, P. (2011). Sustainability Leadership: Linking Theory and Practice. SSRN Electronic Journal, 1-15. https://doi.org/10.2139/ssrn.1947221

United Nations, (2015). Sustainable Development goals. Retrieved October 19, 2018. https://sdgs.un.org/goals

World Economic forum, (2021) Global risks report $2021 \quad$ Retrieved March 15 , 2021. http://www3.weforum.org/docs/WEF_The_Global_Risks_Report_2021.pdf

Zulkiffli, N.A \& Latiffi, A.A (2016). Theoretical Review on Sustainable Leadership (SL) MATEC Web of Conferences 66(5-6):00045. https://doi.org/10.1051/matecconf/20166600045 
Olawale FATOKI has a PhD in Business Management from the University of the Free State South Africa. He is currently a Professor of Business Management at the University of Limpopo, South Africa. His research interests include sustainable business, entrepreneurship and Strategic Management.

ORCHID ID: https://orcid.org/0000-0003-1539-8333

Make your research more visible, join the Twitter account of ENTREPRENEURSHIP AND SUSTAINABILITY ISSUES: @Entrepr69728810

Copyright (C) 2021 by author(s) and VsI Entrepreneurship and Sustainability Center

This work is licensed under the Creative Commons Attribution International License (CC BY).

http://creativecommons.org/licenses/by/4.0/

(c) (7) Open Access 